4. HOUSTON, C.S., and J.K. SCHMUTZ. 1999. Changes in bird populations on Canadian grasslands. Studies in Avian Biology 19:87-94.

5. JACKSON, J.A. 1983. Nesting phenology, nest site selection and reproductive success of Black and Turkey Vultures, pp. 245-270 In S.R. Wilbur and J.A. Jackson,eds., Vulture Biology and Management. University of California Press, Berkeley.
Birds of North America, No. 339 (A. Poole and F. Gill, eds.). Philadelphia: The Birds of North America, Inc.

7. SMITH, A.R. 1996. Atlas of Saskatchewan Birds. Saskatchewan Natural History Society Special Publication \# 22.

8. WAPPLE, G.J. 1985. Nesting Turkey Vulture near Biggar, Saskatchewan. Blue Jay 43:44-46.

6. KIRK, D.A., and M.J. MOSSMAN. 1998.

Turkey Vulture (Cathartes aura). In The

\title{
A BAD YEAR FOR PURPLE MARTINS NEAR SASKATOON
}

\author{
GERALD J. PARENT, RR\#5, Station Main, Saskatoon SK S7K 3J8, and \\ MARY I. HOUSTON, 863 University Drive, Saskatoon SK S7N 0J8
}

Last year, 2001, was the second year that Purple Martins nested in houses provided for them at the site of the former Grasswood grain elevator south of Saskatoon. It was a particularly successful year: 16 pairs laid 81 eggs (a mean of 5.1 eggs per nest); 75 eggs hatched (93\%) and all 75 nestlings fledged. ${ }^{4}$ We now realize that these figures were as high as or exceeded those previously published in the literature: a mean clutch size of 4.2 to 5.0 and a mean fledging rate of $71 \%$ to $85 \% .^{1}$ Studies near Edmonton in 1965 and 1966 showed that females mated to yearling males had a mean clutch size of 4.29 while females mated to adults had a clutch size of 5.00, and the mean fledging rate was $71 \% .^{2}$

In 2002, the Grasswood colony almost doubled in size, increasing from 16 to 30 active pairs. With 132 eggs laid, the mean clutch size was more typical: 4.4 eggs per nest. Sixteen eggs failed to hatch, bringing the hatching rate down to $88 \%$.
Fourteen nests had adult pairs in attendance; thirteen of these were successful and raised 60 young to banding age (4.6 young per successful adult-pair nest or 4.3 young per nest for all adult pairs). The first three broods, all with adult parents, hatched on June 29, July 3 and July 7 . Fifteen nests had yearling pairs, but one of these pairs abandoned its eggs; 54 young from these nests reached banding age (3.7 young per yearling nest attempt). The only nest with an adult mated to a yearling produced only two young. All 116 young were banded when between 8 and 16 days of age, on July 14, 19, 24, and 29.

For the first time in the three-year life of the colony, nestlings died in the nest boxes. The first nestling died of apparent heat stress on July 25, and two, infested with nest mites, died on July 27. Then unseasonable, record-setting cold weather arrived, with the thermometer plunging to $-2^{\circ} \mathrm{C}$ in the early morning of August 2. All 
eight young from two late nests with yearling parents died on August 2. During the cold spell lasting from August 2 to 11, another 31 nestlings died while still in their nests, an additional five were found dead on the ground below the nest boxes, and one drowned in a nearby pond. Only 12 of the dead birds were among the 60 young from nests attended by two adults, a $20 \%$ mortality rate, while the other 28 dead birds were among the 54 young at nests attended by two yearlings, a $52 \%$ mortality rate. Both of the young from the nest with one adult and one yearling died. The young of yearlings fared poorly suggesting that during times of severe cold stress, the fact that adults nest several weeks earlier than yearlings, and possibly have higher efficiency in catching insects, is important.

The mortality in 2002 occurred in spite of major supplemental feeding of the martins. Because many adults seemed lethargic during the cold spell, GJP fed them grasshoppers. He took grasshoppers, 50 at a time, from his deepfreeze, warmed them in the microwave, and in front of the martin houses, sent each grasshopper $10 \mathrm{~m}$ in the air with a blow gun. Sometimes five, six or even seven martins, never once colliding, would swoop at the propelled grasshopper. Usually one of them caught the insect before it hit the ground. About three-quarters of the grasshoppers were eaten by the flying martins, with only a small proportion being fed to the nestlings inside the boxes. After about 100 grasshoppers (about two per adult martin), were fed in this manner, the adults seemed more lively, with sufficient energy to fly out to hunt for more insects. At up to 400 grasshoppers per day, the supply of 2,500 frozen grasshoppers was exhausted by 11 August, the last day of the cold spell.

Kramer and Hill report that most aerial insect prey become inactive at $9^{\circ} \mathrm{C}$. During cold weather in Pennsylvania in May 2002, they sprinkled scrambled eggs on the ground; 25 martins rushed to eat this atypical food. ${ }^{3}$ Thinking that insects would be more natural fare, GJP caught and froze over 2000 grasshoppers in 2001 and 7,500 in 2002. And, after feeding grasshoppers one at a time with a blow gun in 2002 , he developed a new propulsion apparatus using a hose, rubberized nozzle, and an air compressor at 100 psi that can propel three grasshoppers simultaneously even higher in the air to be ready for almost any eventuality in 2003.

\section{Acknowledgements}

We acknowledge keyboarding and editorial assistance from Stuart Houston.

1. BROWN, C.R. 1997. Purple Martin (Progne subis). In The Birds of North America, No. 287 (A. Poole and F. Gill, eds.). The Academy of Natural Sciences, Philadelphia, PA, and the American Ornithologists' Union, Washington, DC.

2. FINLAY, J.C. 1971. Breeding biology of Purple Martins at the northern limit of their range. Wilson Bulletin 83:255-269.

3. KRAMER, P., and J.R. HILL III. 2002. Supplemental feeding reduces May 2002 weather deaths of Purple Martins. Purple Martin Update 11(3):1, 24-26.

4. PARENT, G.J. 2001. Purple Martins attracted to Grasswood. Blue Jay 59:195-199.

"Relative to the enormous numbers of insects destroyed by this species, [purple Martin] as well as the assiduous care of the young in providing them with food, is the now classic example given by Widmann (1884). He watched a colony of 16 pairs of these birds from 4 a.m. to 8 p.m., and during that time the parents came to the young 3,277 times, or an average of 205 times for each pair." Arthur Cleveland Bent, Life Histories of North American Flycatchers, Larks, Swallows and Their Allies. 1963. p. 497. 